\title{
Research on Modelling Novel Internet Finance Pattern under Big Data and Risk-Aware Environment
}

\author{
Xiaochong $\mathrm{Yu}^{1, \mathrm{a}^{*}}$ \\ ${ }^{1}$ Shandong Yingcai University, Jinan, Shandong 250000, China \\ ayuxiaohong122@126.com
}

\begin{abstract}
Keywords: Internet Finance; Big Data Analysis; Risk-Aware Environment; Mathematical Modelling.
\end{abstract}
\begin{abstract}
With the fast and bursting development of finance science and computer technology and in the era of big data and the Internet, Internet companies have adequate advantages of data to step into the financial industry. Data analysis and mining techniques have helped us build more robust and feasible systems ever since. In this paper, we conduct research on modelling novel Internet finance pattern under big data and risk-aware environment. We firstly introduce the principles and concepts of Internet fiancé to act as the prior knowledge. Later, under the big data environment, we learn from static financial data indicators system to dynamic Internet indicators system, mining information related to clients credit qualification. Finally, we make the combination of both the Internet and financing. The result shows the effectiveness of our model. In the future, we plan to conduct research on how to model elements with more prior knowledge and background.
\end{abstract}

\section{Introduction}

With the gradual development of the Internet, human has stepped into the big data era. The size and flexibility, the use of data and data interpretation and application of ability will become an important component of the comprehensive national strength [1]. Own and control data will become the core assets of another country besides land rights, sea power, air-related power. Use big data technology to process and analyze the valuable information of structured data and unstructured data effectively and decision-making model will drive the business model innovation [2]. In the financial field, the Internet companies use big data techniques to analyze customer credit state, conduct Internet financial business, bringing challenges to the traditional financial organization and prompting banks in China to implement innovation in credit risk decision-making model [3]. For example, in the field of credit loans to solve the miniature enterprise financial difficulties, alibaba has launched the credit financing. Now open credit even for ordinary customers, show that the master of micro enterprise loan growth and improve the ability of risk control.

Unlike traditional credit loan, the Internet enterprises collect customer data throughout the Internet at a lower cost. Technology has made the rapid spread of the Internet the best channel to provide banking services and products to the customer. Banks are now considering Internet variables as part of the strategic plan [4]. It will completely change the bank operates, delivery and competition, the competitive advantage especially traditional branch network is rapidly eroded. The bank on the net in many ways is different from traditional Banks to open branches. In the network bank online banking system is a centralized database. All of the services, the bank has been allowed to display in the menu on the Internet. Once the bank branch through the ground or satellite link is connected with each other, it will not have any branch or physical status [5]. This will be a borderless entity allowed at anytime, anywhere, anyhow the banking industry.

Facing with the challenges from the Internet companies and considering the characteristics of web based financing pattern. We conduct research on the issue under the big data environment. In this paper, we introduce our proposed internet finance model with detailed discussion of basic knowledge and the induction procedure. 


\section{Principles of Internet Banking and Financing}

Concept of Internet Banking. Banking is an industry that is based on intensive information, and transactions in banking can normally be consummated without any physical exchange. These elements make a perfect Internet bank passenger vehicle. However, in the initial stage of the bank on the net is through difficulties and failures. The bank on the net is a kind of self-help Banks provide financial services to the customers' network media, including account information inquiry, transfer and online payment. Online banking can communicate online, now even can assess the account information, transaction information, and instant fund transfer, cheques to collect and pay bills the click of a mouse in the city. The basic service of Internet banking is shown in the table 1.

\begin{tabular}{|c|c|c|c|}
\hline Services & Responses & No. $(n=102)$ & Percentage $\%$ \\
\hline \multirow[t]{2}{*}{ Transfer of funds } & Yes & 04 & 3.9 \\
\hline & No & 98 & 96.1 \\
\hline \multirow[t]{2}{*}{ Managing accounts } & Yes & 56 & 54.9 \\
\hline & No & 46 & 45.1 \\
\hline \multirow{2}{*}{$\begin{array}{l}\text { Request for cheque } \\
\text { book }\end{array}$} & Yes & 20 & 19.6 \\
\hline & No & 82 & 80.4 \\
\hline \multirow[t]{2}{*}{ Linking accounts } & Yes & 02 & 2.0 \\
\hline & No & 100 & 98.0 \\
\hline \multirow{2}{*}{$\begin{array}{l}\text { Payment of bills, } \\
\text { premium \&tax }\end{array}$} & Yes & 50 & 49.0 \\
\hline & No & 52 & 51.0 \\
\hline \multirow[t]{2}{*}{ Booking of tickets } & Yes & 24 & 23.5 \\
\hline & No & 78 & 76.5 \\
\hline \multirow{2}{*}{$\begin{array}{l}\text { Trading of mutual } \\
\text { funds, shares \& } \\
\text { investment }\end{array}$} & Yes & 08 & 7.8 \\
\hline & No & 94 & 92.2 \\
\hline \multirow{2}{*}{$\begin{array}{l}\text { Recharge prepaid } \\
\text { mobile }\end{array}$} & Yes & 06 & 5.9 \\
\hline & No & 96 & 94.1 \\
\hline \multirow[t]{2}{*}{ Shopping } & Yes & 60 & 58.8 \\
\hline & No & 42 & 41.2 \\
\hline \multirow[t]{2}{*}{ On-line complaints } & Yes & 18 & 17.6 \\
\hline & No & 84 & 82.4 \\
\hline
\end{tabular}

Table 1 The Basic Services Provided by the Internet Banking

Findings Related to Internet Financing. Shopping was the most common service used by Internet banking users in selected branches of SBI. Customer selected branch of state bank of India also use the bank on the net for the purpose to manage their account, pay bills, insurance and taxes. The proportion of several customers thinks they use online banking to check books and online complaints. The level of satisfactory is shown in the table 2 .

\begin{tabular}{|l|l|l|}
\hline Level of satisfaction & No of responses & Percentage \\
\hline Highly satisfied & 02 & 2.0 \\
\hline Satisfied & 42 & 41.2 \\
\hline Undecided & 48 & 47.0 \\
\hline Dissatisfied & 08 & 7.8 \\
\hline Highly dissatisfied & 02 & 2.0 \\
\hline
\end{tabular}

Table 2 The Satisfactory Level Result

\section{Our Proposed Model and Methodology}

Trust Degree Modelling. If the micro enterprises trust degree is high, it will lead to customer loyalty and word of mouth effect, lead to increase the number of wealth accumulation and business. Enjoy 
special financial industry in the developed market economy countries, so often impose taxes than other industries. Related tax include value added tax, stamp tax, securities exchange tax and enterprise income tax, individual income tax, etc., usually with income tax than indirect taxes accounted for a larger proportion. The rapid development of the network financial nature leads to disputing over whether and how to set up tax. In the past twenty years, the market economy developed countries share different opinion whether tax of network finance and they gradually reached a consensus, which can provide reference for China's Internet financial tax legislation. Credit evaluation system which is also named as CES indicates the following guild-lines.

$$
\begin{aligned}
& T_{D}=1-a^{p}(0<a<1) \\
& T_{I}=\left\{\begin{array}{cc}
1-a^{p-n}, & p>n \\
0, & \text { others }
\end{array}\right. \\
& T=w \cdot T_{D}+(1-w) \cdot T_{I}
\end{aligned}
$$

These descriptions show that trust can be measured data environment. Model can trust and the bank's mission is to fully mining related data, such as the frequency of successful trading.

Quality Assessment and Evaluation. The quality of products and services to reflect the millo enterprise reputation and ability in an impregnable position in the intense market competition, so the quality of products and services is reliable credit judgment standard. From the perspective of e-commerce in the process, usually every customer's products and services to the microscopic enterprise after each transaction, the bank can focus on data mining in customer evaluation system or data from the entire supply chain platform, miniature enterprise participation, including structured data and unstructured data. In China related to development and stability of the tax management system, it is very necessary, on the basis of scientific analysis, the pace of legislation, make the top Internet financial tax system design and classification of network financial taxation scope of VAT pilot reform standardize the financial industry, the healthy development of the Internet in the process of tax reform. In fact, the current Internet financial tax law is lagging behind and lack of the system design needs to change the law as a personal income tax, such as law, law of the interim regulations on enterprise income tax, business tax, the interim regulations on value-added tax and tax management, so that they can meet the needs of the development of network finance, in the form of specification. In addition, any legal cases, the network financial tax can post is available and the current lack of effective supervision of the tax law need to be improved as soon as possible. In addition, the bank also can create a secondary

\begin{tabular}{|c|c|c|c|}
\hline \multicolumn{4}{|c|}{ static objective credit risk indicators system } \\
\hline first class indicators & $\begin{array}{c}\text { weight } \\
\text { distribution }\end{array}$ & secondary indicators & $\begin{array}{c}\text { weight } \\
\text { distribution }\end{array}$ \\
\hline \multirow{3}{*}{ operational ability } & \multirow{3}{*}{$A 1$} & accounts receivable turnover & $B 1$ \\
\hline & & inventory turnover & $B 2$ \\
\hline & & fixed assets turnover & B3 \\
\hline \multirow{3}{*}{ profitability } & \multirow{3}{*}{$A 2$} & net profit margin & B4 \\
\hline & & return on total assets & $B 5$ \\
\hline & & profit margin on net assets & B6 \\
\hline \multirow{3}{*}{ debt-paying ability } & \multirow{3}{*}{$A 3$} & quick ratio & $B 7$ \\
\hline & & cash ratio & $B 8$ \\
\hline & & asset-liability ratio & $B 9$ \\
\hline \multirow[b]{2}{*}{ development ability } & \multirow[b]{2}{*}{$A 4$} & total assets growth & $B 10$ \\
\hline & & operating profit growth ratio & $B 11$ \\
\hline
\end{tabular}
index in the quality of products and services: product quality, product description, fidelity and the service attitude and after-sales service. The assessment elements are shown in the table 3.

Table 3 The Elements for Quality Assessment 
Modelling and Simulation Procedure. For investment institutes, micro enterprises credit risk decision making can form up of the multi-indicator linear weighted algorithm to form the following formula:

$$
Z=\sum_{i=B_{1}}^{B_{3}} G_{A 1 i} \cdot W_{A 1 i} \cdot W_{A 1}+\sum_{i=B_{4}}^{B_{6}} G_{A 2 i} \cdot W_{A 2 i} \cdot W_{A 2}+\sum_{i=B_{7}}^{B_{9}} G_{A 3 i} \cdot W_{A 3 i} \cdot W_{A 3}
$$

Qualitative and quantitative indicators have different processing method, so the evaluation standard system and grade-calculating methods need to be confirmed for each indicator, it is convenient to calculate.

\section{Big Data Environment Description}

Overview of Big Data Environment. Banks should realize financial industry competition is the competition data usage of the future. By optimizing the distribution of the data resource industry and the input data, Banks can effectively use data mining tools. Through data analysis and processing technology, can focus on decentralized information, become isolated information related information and useless data into valuable information, to achieve the optimal allocation of resources, reduce the blindness of decision making, this is a very important direction of information construction of the bank. Data mining techniques could be combined with the model.

The Combination with Finance. One of the main reasons why the Internet companies can microenterprise credit loan business development is the advantage of big data. Alibaba, for example, through customer basic information, real-time data updates, study of micro enterprise demand and credit qualification. In addition, it covers the function of financing, payment and the medium of exchange, mainly reflected in the rise of the third party payment methods such as online P2P loans and financing, including P2P lending financial business of revolutionary significance. No tax law on the Internet can be exclusive or system financing, because it is in China's development is still in its infancy. Existing law on personal income tax, enterprise income tax law, the interim regulations on business tax, some of the interim regulations on value-added tax is applicable to Internet finance although there are many laws still exist emptiness and ambiguous, need to speed up the legislative regulation. With the reconstruction of banks data system under the big data strategy, accordingly, they should also strengthen the construction of big data talents. Data management talents is needed to prevent Internet attacks and leakage of user privacy caused by malicious use of data resources; data mining and analytical talents should explore new data mining tools and analysis methods.

\section{Summary and Conclusion}

In the era of big data and the Internet, Internet companies have adequate advantages of data to step into the financial industry. Data analysis and mining techniques have helped us build more robust and feasible systems ever since. In this paper, we conduct research on modelling novel Internet finance pattern under big data and risk-aware environment. We firstly introduce the principles and concepts of Internet fiancé to act as the prior knowledge. Later, under the big data environment, we learn from static financial data indicators system to dynamic Internet indicators system, mining information related to clients credit qualification. Finally, we make the combination of both the Internet and financing, the result shows the effectiveness of our model. In the future, we plan to conduct research on how to model elements with more prior knowledge and background.

\section{References}

[1] An, J., et al. "The Internet Finance in China: The Living Space and the Regulations." Indian Journal of Science and Technology 8.S4 (2015): 106-114. 
[2] ZHANG, Fuqiang, and W. U. Yifan. "A Legal Reflection on Reform of Internet Finance Tax." International Business and Management 10.1 (2015): 18-22.

[3] La Raja, Ray. "Campaign finance laws that make small donations public may lead to fewer people contributing and to smaller donations." USApp-American Politics and Policy Blog (2015).

[4] Jones, Joseph M., and Leo R. Vijayasarathy. "Internet Shopping: Findings from an Exploratory Study and Research Propositions." Proceedings of the 1998 Academy of Marketing Science (AMS) Annual Conference. Springer International Publishing, 2015.

[5] Khan, Mohd Noor Azli Ali. "Internet Financial Reporting in Malaysia: Preparers' and Users' Perceptions." Procedia-Social and Behavioral Sciences 172 (2015): 778-785. 